\title{
Severe Anemia in Patients with Propionic Acidemia is Associated with Low Plasma Levels of Valine, Isoleucine and Methionine
}

Sinziana Stanescu ( $\nabla$ sinziana.stanescu@salud.madrid.org )

Hospital Universitario Ramon y Cajal https://orcid.org/0000-0003-0340-4580

Amaya Belanger-Quintana

Hospital Universitario Ramon y Cajal

Victor Quintero

Hospital Universitario Ramon y Cajal

Maria Soledad Maldonado

Hospital Universitario Ramon y Cajal

Francisco Arrieta

Hospital Universitario Ramon y Cajal

Patricia Alcaide

Centro de Diagnostico de Enfermedades Moleculares, Facultad Autónoma de Madrid

Mercedes Martínez-Pardo

Hospital Universitario Ramon y Cajal

Research article

Keywords: propionic acidemia, anemia, diet, protein-restricted

Posted Date: August 28th, 2020

DOl: https://doi.org/10.21203/rs.3.rs-62348/v1

License: (c) (1) This work is licensed under a Creative Commons Attribution 4.0 International License.

Read Full License 


\section{Abstract}

Background. Propionic acidemia (AP), an inborn error of metabolism, is caused by a deficiency in propionyl-CoA carboxylase. Patients have to follow a diet restricted in the propiogenic amino acids isoleucine (Iso), valine (Val), methionine (Met) and threonine (Thr); proper adherence can prevent and treat acute decompensation and increase life expectancy. However, chronic complications occur in several organs even though metabolic control may be largely maintained. Bone marrow aplasia and cytopenia are among the more common.

Materials and methods. In this retrospective study, data for patients with PA being monitored at the Hospital Ramón y Cajal (Madrid, Spain) $(\mathrm{n}=10)$ were examined to statistically detect relationships between hematological complications outside of metabolic decompensation episodes, and plasma amino acids provided by the diet, urinary organic acids and plasma odd-chain fatty acids. High ferritin levels were deemed to indicate that a patient had received repeated transfusions for severe anemia since data on hemoglobin levels at the moment of transfusion were not always passed on by the attending centers.

Results. Three patients had severe, persistent anemia that required repeated blood transfusions leading to high ferritin levels. Their low plasma Val, Ile and Met suggested that their anemia had a nutritional component.

Conclusion. The present results suggest that severe anemia in patients with PA is associated with low plasma levels of Val, lle and Met.

\section{Background}

Propionic acidemia (PA; OMIM 606054) is a rare, inherited (autosomic recessive) metabolic disease caused by a deficiency in propionyl-CoA carboxylase, a mitochondrial enzyme that transforms propionylCoA into methylmalonyl-CoA. Propionyl-CoA is an intermediate in the metabolism of the amino acids isoleucine (lle), valine (Val), methionine (Met) and threonine (Thr). Other sources of propionyl-CoA include odd-numbered long-chain fatty acids (OLCFAs), cholesterol, and propionic acid generated by anaerobic bacteria performing fermentation in the intestine (Fig. 1). Propionyl-CoA deficiency leads to the accumulation of 3-hydroxy propionic acid and methyl citrate (resulting from the combination of propionyl-CoA and oxaloacetate), propionyl carnitine and tiglyl glycine among other abnormal intermediates of propionyl-CoA metabolism (1).

Commonly beginning in neonatal life, patients with PA experience acute metabolic decompensation during scenarios involving increased catabolism, e.g., infections or prolonged fasting. These episodes are the result of intoxication by alternative metabolism products, leading to hypoglycemia, ketosis, hyperammonemia, and multiorgan failure (2). Patients with PA - even those who manage to control their metabolism well - eventually suffer chronic complications involving organs with high energy demands, e.g., the central nervous system (encephalopathy, abnormal movements, epilepsy, psychomotor delay, 
ataxia, lesions in the basal ganglia similar to those seen in Leigh's syndrome, and atrophy of the optic nerve), the heart (dilated cardiomyopathy, arrhythmias), the skeletal muscles (myopathy), bone marrow (bone marrow aplasia, cytopenia), and the gastrointestinal tract (pancreatitis, hepatitis), etc (3). No complete pathophysiological explanation for this is yet available. Treatment is based largely on dietary protein restriction to limit the intake of amino acids providing precursors of propionyl-CoA (Met, Thr, Val and Ile), plus the administration of carnitine and metronizadole (2) (4)

The main aim of the present work was to detect the possible relationships between severe anemia in patients with PA outside of metabolic decompensation episodes, and plasma amino acids, urinary organic acids, and OLCFAs.

\section{Materials And Methods}

The medical records of patients with PA being monitored at the Metabolic Disease Unit, Hospital de Ramón y Cajal (Madrid, Spain) ( $\mathrm{N}=10)$, were examined in order to identify those with significant hematological complications outside of metabolic decompensation episodes. Since these patients receive periodic transfusions of blood derivatives at hospitals other than the above, high plasma ferritin (iron overload) was used as a marker of those who had received repeated transfusions for severe anemia. This proxy was employed since hemoglobin levels at the moment of transfusion were not available for all patients (they were not passed on by all attending centers); plasma ferritin concentrations, however, were available. Relationships were sought between plasma ferritin, platelet and neutrophil counts, and the plasma levels of Iso, Val, Met, Thr, Leucine (Leu) and glycine (Gly), the urine concentrations of 3-hydroxy propionic acid and methyl citrate, and plasma OLCFAs. Periods of metabolic decompensation were not taken into account in analyses since severe pancytopenia can occur at such times. Periods during which the patients were suffering from an infection were also excluded given the possible interference with ferritin concentrations.

Amino acids in plasma/serum were analyzed by ion-exchange chromatography with ninhydrine. Organic acids were determined as trimethylsilyl derivatives by GC-MS after urease treatment and ethyl acetate liquid-liquid extraction without oxymation. Odd long-chain fatty acids in plasma/serum were analyzed by gas chromatography coupled to flame ionization detection. All lab measurements were completed in our ERNDIM approved, reference laboratory (CEDEM, Centro de Diagnostico de Enfermedades Moleculares, Universidad Autonoma, Madrid).

Severe dietary protein restriction was defined as an intake of natural protein of high biological value (PHBV) of $<10 \mathrm{~g} /$ day. The severity and persistence of anemia was classified in terms of patient plasma ferritin concentration (i.e., an indication of whether or not they received necessary transfusions): $<300 \mathrm{ng} / \mathrm{ml}$ (normal ferritin: 15-200 ng/ml) = no significant anemia with no need for transfusions; 300$1000 \mathrm{ng} / \mathrm{ml}=$ moderate anemia; and $>1000 \mathrm{ng} / \mathrm{ml}$ = severe anemia requiring periodic transfusions.

The means and the 25th and 75th percentiles for plasma amino acids, urinary organic acids and plasma OLCFAs, were contrasted against PHBV intake and plasma ferritin. The Kruskal-Wallis test was used to 
compare the differences between anemia classification groups (no significant, moderate or severe anemia). When pairwise comparisons were necessary, the Mann-Whitney $\mathrm{U}$ test was used with Bonferroni correction and significance was established for $p$-value $<0.05$. All analyses were performed using IBM SPSS Statistics software.

\section{Results}

3/10 patients (aged 2-25 years) showing persistent severe anemia and requiring repeated transfusions, provided by their attending hospitals when hemoglobin concentrations of $<7.5 \mathrm{~g} / \mathrm{dl}$ were detected. Table 1 shows the demographic and clinical characteristics of the patients. The iron overload caused by these transfusions led all three to require iron chelation treatment with deferasirox (Exjade $\rightarrow$ ). All three were diagnosed when neonates, and at the time of study they all showed multisystem disease with different chronic complications. Severe anemia appeared in all three when their PHBV intake was reduced to $<10 \mathrm{~g} /$ day. Two of these patients received treatment with erythropoietin, but without benefit.

Table 1

Demographic and clinical data of 3 PA patients with severe anemia included in the study

\begin{tabular}{|c|c|c|c|c|c|}
\hline & Sex & $\begin{array}{l}\text { Current } \\
\text { age } \\
\text { (years) }\end{array}$ & $\begin{array}{l}\text { Age at } \\
\text { diagnosis }\end{array}$ & Genetics & $\begin{array}{l}\text { Clinical course (long term } \\
\text { complications) }\end{array}$ \\
\hline 1 & $M$ & $\begin{array}{l}\text { Died } \\
(5)\end{array}$ & neonatal & $\begin{array}{l}\text { PCCA gene } \\
\text { p.Leu470Arg/p.Leu470Arg }\end{array}$ & $\begin{array}{l}\text { Severe neuromotor delay } \\
\text { Choreoathetosis, basal ganglia } \\
\text { involvement, leukopenia, } \\
\text { frequent infections, dilated } \\
\text { cardiomyopathy, pancreatitis; } \\
\text { severe anemia }\end{array}$ \\
\hline 2 & $M$ & 9 & neonatal & $\begin{array}{l}\text { PCCB gene } \\
\text { p.Gly407Argfs*14/ } \\
\text { p. Arg410Trp }\end{array}$ & $\begin{array}{l}\text { Severe neuromotor delay, } \\
\text { severe anemia, leukopenia }\end{array}$ \\
\hline 7 & $\mathrm{~F}$ & 29 & neonatal & $\begin{array}{l}\text { PCCB gene } \\
\text { p.Gly407Argfs }{ }^{\star} 14 / \text { p.Arg165Gln } \\
+ \text { p.Ala497Val }\end{array}$ & $\begin{array}{l}\text { Peripheric neuropathy, } \\
\text { neuromotor delay, pancreatitis, } \\
\text { thrombopenia }\end{array}$ \\
\hline
\end{tabular}

A moderate PHBV restriction $>10 \mathrm{~g} /$ day was associated with higher Val plasma levels ( $p$-value 0.03 ), lower ferritin $(p$-value $<0.01)$ and higher platelet count $(p$-value $<0.04)$. Curiously, a higher PHBV intake (> $10 \mathrm{ng} /$ day) was associated with an important reduction in plasma OLCFAs ( $p$-value $<0.02)$, but with no significant increase in the metabolic markers 3-hydroxy propionic acid and methyl citrate (Table 2; Fig. 2). 
Table 2

Values for metabolic, nutritional and hematological variables with respect to intake of proteins of high biological value.

\begin{tabular}{|c|c|c|c|}
\hline & $\begin{array}{l}\text { Severe dietary protein restriction } \\
(\mathrm{PHBV}<10 \mathrm{~g})\end{array}$ & $\begin{array}{l}\text { Moderate dietary protein restriction } \\
(\mathrm{PHBV}>10 \mathrm{~g} / \mathrm{d})\end{array}$ & $\begin{array}{l}p- \\
\text { value }\end{array}$ \\
\hline & $\mathrm{n}=\mathbf{2 2}$ & $\mathrm{n}=\mathbf{2 8}$ & \\
\hline Glycine (Gly) & $480(358 ; 658)$ & $456(779 ; 948)$ & n.a. \\
\hline $\begin{array}{l}\text { Isoleucine } \\
\text { (lle) }\end{array}$ & $19(13 ; 21)$ & $22(17 ; 30)$ & n.a. \\
\hline Leucine (Leu) & $56(40 ; 90)$ & $59(48 ; 85)$ & n.a. \\
\hline Valine (Val) & $47(31 ; 56)$ & $56(41 ; 75)$ & 0.03 \\
\hline $\begin{array}{l}\text { Methionine } \\
\text { (Met) }\end{array}$ & $10(8 ; 13)$ & $12(10 ; 13)$ & n.a. \\
\hline $\begin{array}{l}\text { Threonine } \\
\text { (Thr) }\end{array}$ & $41(33 ; 51)$ & $48(32 ; 53)$ & n.a. \\
\hline OLCFAs & $8.7(6.8 ; 11.7)$ & $5.1(3.4 ; 7.8)$ & 0.02 \\
\hline Methyl-citrate & $1273(684 ; 2083)$ & $1340(516 ; 2125)$ & n.a. \\
\hline $\begin{array}{l}3 \mathrm{OH} \\
\text { propionic } \\
\text { acid }\end{array}$ & $422(229 ; 729)$ & $617(256 ; 784)$ & n.a. \\
\hline Platelet count & $196000(143000 ; 243000)$ & $275000(199000 ; 358000)$ & 0.04 \\
\hline $\begin{array}{l}\text { Neutrophils } \\
\text { count }\end{array}$ & $1580(1005 ; 2395)$ & $1710(1590 ; 2530)$ & n.a. \\
\hline Ferritin & $865(565 ; 1041)$ & $285(176 ; 432)$ & 0.01 \\
\hline
\end{tabular}

The plasma Ile, Val and Met values were significantly lower when ferritin levels were higher (i.e., after repeated transfusions for severe anemia) (Fig. 3). No association was seen between urine 3-hydroxy propionic acid nor methyl citrate and ferritin. Nor was any seen between the OLCFAs concentration and plasma ferritin (Table 3). However, thrombocytopenia was associated with high concentrations of urinary methyl citrate ( $p$-value < 0.02$)$, and with increased plasma Gly ( $p$-value< 0.01$)$. No association was seen between the neutrophil count and any of the amino or organic acids studied. 
Table 3

Values for nutritional and metabolic markers with respect to plasma ferritin.

\begin{tabular}{|c|c|c|c|c|c|c|c|}
\hline & \multirow{2}{*}{$\begin{array}{l}\text { Ferritin< } \\
300 \mathrm{ng} / \mathrm{ml} \\
(0) \\
\mathrm{n}=18\end{array}$} & \multirow{2}{*}{$\begin{array}{l}\text { Ferritin: 300- } \\
1000 \mathrm{ng} / \mathrm{ml} \text { (1) } \\
\mathrm{n}=18\end{array}$} & \multirow{2}{*}{$\begin{array}{l}\text { Ferritin > } \\
1000 \mathrm{ng} / \mathrm{ml} \\
(2) \\
\mathrm{n}=10\end{array}$} & \multirow[t]{2}{*}{$\begin{array}{l}p- \\
\text { value }\end{array}$} & \multicolumn{3}{|c|}{$\begin{array}{l}\text { Pairwise } \\
\text { comparisons } \\
\text { p-value }\end{array}$} \\
\hline & & & & & $\begin{array}{l}0 \\
\text { vs. } \\
1\end{array}$ & $\begin{array}{l}0 \text { vs. } \\
2\end{array}$ & $\begin{array}{l}1 \\
\text { vs. } \\
2\end{array}$ \\
\hline $\begin{array}{l}\text { Glycine } \\
\text { (Gly) }\end{array}$ & $\begin{array}{l}871(780 ; \\
971)\end{array}$ & $543(429 ; 744)$ & $\begin{array}{l}379(323 ; \\
561)\end{array}$ & $<0.001$ & 0.01 & $<.001$ & 0.03 \\
\hline $\begin{array}{l}\text { Isoleucine } \\
\text { (lle) }\end{array}$ & $26(21 ; 31)$ & $16(11 ; 19)$ & $18(12 ; 20)$ & 0.01 & 0.02 & 0.007 & 0.5 \\
\hline $\begin{array}{l}\text { Leucine } \\
\text { (Leu) }\end{array}$ & $55(47 ; 108)$ & $54(39 ; 69)$ & $64(41 ; 107)$ & n.a. & n.a. & n.a. & n.a. \\
\hline Valine (Val) & $64(53 ; 78)$ & $44(31 ; 56)$ & $31(22 ; 46)$ & $\begin{array}{l}<.001 \\
0.00\end{array}$ & 0.1 & $\begin{array}{l}< \\
0.001\end{array}$ & 0.01 \\
\hline $\begin{array}{l}\text { Methionin } \\
\text { (Met) }\end{array}$ & $12(11 ; 13)$ & $9(8 ; 14)$ & $9(7 ; 11)$ & 0.01 & 0.1 & 0.004 & 0.1 \\
\hline $\begin{array}{l}\text { Threonine } \\
\text { (Thr) }\end{array}$ & $48(47 ; 51)$ & $34(33 ; 47)$ & $46(29 ; 54)$ & n.a. & n.a. & n.a. & n.a. \\
\hline OLCFAs & $\begin{array}{l}3.7(3.3 ; \\
8.7)\end{array}$ & $7.8(5.4 ; 8.7)$ & $6.6(5.3 ; 9.9)$ & n.a. & n.a. & n.a. & n.a. \\
\hline $\begin{array}{l}\text { Methyl } \\
\text { citrate }\end{array}$ & $\begin{array}{l}1744(1340 ; \\
2646)\end{array}$ & $1101(591 ; 1747)$ & $\begin{array}{l}776(595 \text {; } \\
1954)\end{array}$ & n.a. & n.a. & n.a. & n.a. \\
\hline $\begin{array}{l}3 \mathrm{OH} \\
\text { propionic } \\
\text { acid }\end{array}$ & $\begin{array}{l}606(265 ; \\
776)\end{array}$ & $417(220 ; 790)$ & $\begin{array}{l}647(347 \text {; } \\
744)\end{array}$ & n.a. & n.a. & n.a. & n.a. \\
\hline
\end{tabular}

\section{Discussion}

The long-term complications suffered by patients with PA affects their prognosis (3). Certainly, they increase morbidity and mortality rates outside of the influence of acute decompensation episodes. Pancytopenia has generally been described as occurring during periods of acute decompensation, but patients can also experience anemia, neutropenia or thrombocytopenia outside of these times (2).

Given the small number of patients with PA, the actual prevalence of hematological complications is unknown. A recent meta-analysis determined anemia to be more common than cardiomyopathy or lesions in the basal ganglia (3). In another study of the long-term complications of organic acidemia and urea cycle disorders (as recorded in the European Registry of Organic Acidemia and Urea Cycle 
Disorders), the not prevalence of anemia among patients with PA was determined to be $22 \%$, while figures for leucopenia and thrombocytopenia reached $18 \%$ (5). The reason for these hematological problems may lie in the toxicity of accumulating metabolites such as 3-hydroxy propionic acid, methyl citrate or tiglyl glycine, a lack of certain nutrients (5), or mitochondrial dysfunction (3). The pancytopenia seen during decompensation episodes is generally reversible (6), (7), (2), supporting the idea that accumulating toxic metabolites are to blame. However, why hematological problems should occur during times of metabolic stability remains unclear.

The blood is a tissue with a high regeneration rate. The need for nutrients - especially amino acids - is therefore high compared to other tissues, leaving the hematopoietic tissue sensitive to malnutrition (8). Certainly, anemia associated with protein-energy malnutrition is relatively common in children and elderly people in general (9). The constant production of blood cells from hematopoietic stem cells (HCS) is also influenced by the latter's microenvironment, a complex biological niche (10). In recent years, interest has grown in understanding the influence of diet on the physiology and viability of HCS. Several studies, particularly those investigating the pre-transplant conditioning of the bone marrow, have shown the influence exerted by dietary branched-chain amino acids and cysteine (Cys) on the function of HSC and their microenvironment. Indeed, Val and Cys have been reported indispensable for the maintenance of HSC (11). In vitro, neither human nor rat HSC can proliferate in media without these amino acids, and rats fed a Val-restricted diet show a reduced HSC count within a week (11). In another study that examined the effect of branched-chain amino acid balance on HSC viability, restricting the Val intake by $10 \%$ led to a significant fall in HSC numbers. The same $10 \%$ restriction in Val in the presence of increased lle and Leu led to the complete blockage of HSC proliferation (12), although it is difficult to explain why.

The above evidence suggests that a low intake of Val compared to a normal/high intake of Leu and Ile can have a negative effect on the bone marrow. Certainly, among the present patients, the association between reduced plasma Val and lle and high plasma ferritin highlights a relationship between the persistence and severity of anemia and diet.

The diet of patients with AP is restricted in Val and lle and provides normal or high amounts of Leu, but during emergency treatment the intake of PHBV needs to be reduced or even suspended altogether (2). Such periods of instability can be common during the first years of life, resulting in considerable fluctuations in the PHBV intake. According to recommendations made by the latter authors, lle supplements can be given to prevent acrodermatitis dysmetabolica associated with low lle plasma levels(2) and all the patients included in the study received lle supplements in order to avoid the dermatological complications. This might lead to a situation of very low intake of Val compared to a higher intake of Ile and a normal Leu. With the exception of a single old study in animal models (13), the literature contains little information on the toxicity of Val deficiency.

Mitochondrial dysfunction has also been proposed to underlie the hematological complications seen in PA (3). This dysfunction might be caused by the toxicity of 3-hydroxy propionic acid and methyl citrate (14), (15), (16), (17) (18), an increase in oxidative stress, and a reduction in antioxidant capacity (19) (20), 
(21) (22) (23) (24). Met is involved in antioxidant defenses via the synthesis of glutathione from Cys in the liver and and it was reported that HSC proliferation was also dependent on Cys as well as Val (11). It also participates in the synthesis of S-adenosyl-L-methionine (SAM) via transmethylation reactions. Recent studies have revealed the role of SAM in the protection of cells from oxidative stress induced by different toxins and free radicals (25). In the present patients, low plasma Met was also associated with high plasma ferritin revealing the need for transfusions, pointing to a likely deficiency in bone marrow antioxidant defenses.

The present results support the idea that anemia during metabolically stable periods in patients with AP has a nutritional component. The need for transfusion appeared when the PHVB intake fell below $10 \mathrm{~g} /$ day. The high ferritin levels resulting from repeated blood transfusions are associated with reduced plasma Val, lle and Met. However, the toxicity of 3-hydroxy propionic acid and methyl citrate in the bone marrow, while normally thought to be associated with acute decompensation, should not yet be ruled out as a cause of chronic severe anemia. The present results also show high urine methyl citrate and plasma Gly to be associated with thrombocytopenia.

Imbalances between branched-chain amino acids have been reported by other authors to have undesirable metabolic effects in patients with PA and MMA (26). Also, excess Leu was found to reduce plasma Val and lle by interfering with the LAT1 transport of amino acids (27). In addition, animals fed high doses of Leu show low central nervous system concentrations of tryptophan (Trp), Val, lle, Met and low brain alanine (Ala), which might affect the synthesis of neurotransmitters (28). Other authors have reported the importance of branched-chain amino acid equilibrium in body growth and cellular immunity in animal models (29), (30).

The reason why HSC are so sensitive to a reduced Val intake and to disequilibrium between branchedchain amino acids has not been explored. However, it may involve Val's role as a structural unit of proteins, or some relationship with cell signaling.

The present work is the first to provide positive evidence of a nutritional component underlying the hematological complications of AP during stable metabolic periods, adding weight to other authors' suspicions (26). For patients with PA, ways to maximize protein intake while reducing the intake of Leu need to be found.

The small number of patients examined is a limitation of the present work. Confirmatory studies involving international registries should be performed.

\section{Conclusion}

Patients with PA can experience serious hematological complications even during periods of metabolic stability. The severe anemia they commonly suffer may be due an imbalance in the intake of branchedchain amino acids and a deficient intake of Met. Further work is needed to confirm the importance of the diet in the development of long-term hematological complications in patients with AP. 


\section{Abbreviations}

PA: propionic acidemia; Val: Valine; lle: Isoleucine; Leu: Leucine; Met: Methionine; Thr: Threonine; Gly: Glycine; BCAA: branched-chain amino acids; OLCAFs: odd-numbered long chain fatty acids; n.a.: not applicable

\section{Declarations}

\section{Role of Sponsor:}

This work was supported by the "Ramon Areces" Foundation (grant number CIVP17A2827).

The study was approved by the Ethical Committee of our hospital (Hospital Universitario Ramon y Cajal, Madrid, Spain).

Dr Stanescu had a significant contribution to the conception and design of the study. Drs BelangerQuintana and Dr Quintero had contributed to the acquisition and interpretation of the data. All authors have contributed to the interpretation of the data and gave the final approval for the article.

Data and materials are available upon request.

\section{Ethics statement:}

This article does not contain any studies with human or animal subjects performed by any of the authors.

\section{Authors' Disclosures or Potential Conflicts of Interest:}

Sinziana Stanescu, M.D. has received travel and speaker fees from Nutricia, Mead Johnson, Genzyme, Recordatti Rare Diseases, Vitaflo-Nestlé, BioMarin.

Amaya Belanger-Quintana, Ph.D. has received travel and speaker fees from Nutricia, Mead Johnson, Genzyme, Recordatti Rare Diseases, Vitaflo-Nestlé, Takeda, BioMarin; advisory fees from BioMarin and Merk Serono.

Victor Quintero Ph.D. declares that he has no conflict of interest

Francisco Arrieta Ph.D. has received travel and speaker fees from Nutricia, Mead Johnson, Recordatti Rare Diseases, Vitaflo-Nestlé, BioMarin.

Patricia Alcaide Ph.D. declares that she has no conflict of interest.

Maria Soledad Maldonado Ph.D. declares that she has no conflict of interest.

Mercedes Martínez-Pardo Ph.D has received travel and speaker fees from Nutricia, Mead Johnson, Genzyme, Recordatti Rare Diseases, Vitaflo-Nestlé, Takeda, BioMarin. 


\section{Bibliography}

1. Wongkittichote P, Ah Mew N, Chapman KA. Propionyl-CoA carboxylase - A review. Mol Genet Metab 2017; 122:145-52.

2. Baumgartner MR, Hörster F, Dionisi-Vici C, et al. Proposed guidelines for the diagnosis and management of methylmalonic and propionic acidemia. Orphanet J Rare Dis. 2014;9:130.

3. Haijes HA, Jans JJM, Tas SY, Verhoeven-Duif NM, van Hasselt PM. Pathophysiology of propionic and methylmalonic acidemias. Part 1: Complications. J Inherit Metab Dis. 2019;42:730-44.

4. Haijes HA, van Hasselt PM, Jans JJM, Verhoeven-Duif NM. Pathophysiology of propionic and methylmalonic acidemias. Part 2: Treatment strategies. J Inherit Metab Dis. 2019;42(5):745-61.

5. Kölker S, Valayannopoulos V, Burlina AB, et al.The phenotypic spectrum of organic acidurias and urea cycle disorders. Part 2: the evolving clinical phenotype. J Inherit Metab Dis. 2015;38:1059-74.

6. Stork LC, Ambruso DR, Wallner SF, Sambrano JE, Moscinski LC, Wilson HL, McCabe ER. Pancytopenia in propionic acidemia: hematologic evaluation and studies of hematopoiesis in vitro. Pediatr Res. 1986;20:783-8.

7. Inoue S, Krieger I, Sarnaik A, Ravindranath Y, Fracassa M, Ottenbreit MJ Inhibition of bone marrow stem cell growth in vitro by methylmalonic acid: a mechanism for pancytopenia in a patient with methylmalonic acidemia. Pediatr Res. 1981;15:95-8.

8. Santos EW, Oliveira DC, Silva GB, Tsujita M, Beltran JO, Hastreiter A, Fock RA, Borelli P. Hematological alterations in protein malnutrition. Nutr Rev. 2017;75:909-919.

9. Bianchi VE. Role of nutrition on anemia in elderly. Clin Nutr ESPEN. 2016;11:e1-e11.

10. Wilkinson AC, Yamazaki S. The hematopoietic stem cell diet. Int J Hematol. 2018;107:634-41.

11. Taya Y, Ota Y, Wilkinson AC, Kanazawa A, Watarai H, Kasai M, Nakauchi H, Yamazaki S. Depleting dietary valine permits nonmyeloablative mouse hematopoietic stem cell transplantation. Science. 2016;354:1152-5.

12. Wilkinson AC, Morita M, Nakauchi H, Yamazaki S. Branched-chain amino acid depletion conditions bone marrow for hematopoietic stem cell transplantation avoiding amino acid imbalance-associated toxicity. Exp Hematol. 2018;63:12-16.e1.

13. Cusick PK, Koehler KM, Ferrier B, Haskell BE. The neurotoxicity of valine deficiency in rats. J Nutr. 1978;108:1200-6.

14. Schwab MA, Sauer SW, Okun JG, Nijtmans LGJ, Rodenburg RJT, van den Heuvel LP, Dröse S, Brandt U, Hoffmann GF, Laak HT, Kölker S, Smeitink JAM. Secondary mitochondrial dysfunction in propionic aciduria: a pathogenic role for endogenous mitochondrial toxins. Biochem J. 2006;398:107-12.

15. Brock $M$, Buckel W. On the mechanism of action of the antifungal agent propionate Propionyl-CoA inhibits glucose metabolism in Aspergillus nidulans. Eur J Biochem. 2004;271:3227-41.

16. Maruyama K, Kitamura H. Mechanisms of growth inhibition by propionate and restoration of the growth by sodium bicarbonate or acetate in Rhodopseudomonas sphaeroides. J Biochem. 1985;98:819-24. 
17. Gregersen $\mathrm{N}$. The specific inhibition of the pyruvate dehydrogenase complex from pig kidney by propionyl-CoA and isovaleryl-CoA. Biochem Med. 1981;26:20-7.

18. Cheema-Dhadli S, Leznoff CC, Halperin ML. Effect of 2-methylcitrate on citrate metabolism: implications for the management of patients with propionic acidemia and methylmalonic aciduria. Pediatr Res. 1975;9:905-8.

19. Gallego-Villar L, Pérez-Cerdá C, Pérez B, Abia D, Ugarte M, Richard E, Desviat LR. Functional characterization of novel genotypes and cellular oxidative stress studies in propionic acidemia. $\mathrm{J}$ Inherit Metab Dis. 2013;36:731-40.

20. Mc Guire PJ, Parikh A, Diaz GA. Profiling of oxidative stress in patients with inborn errors of metabolism. Mol Genet Metab. 2009;98:173-80.

21. Ribas GS, Biancini GB, Mescka C, Wayhs CY, Sitta A, Wajner M, Vargas CR. Oxidative stress parameters in urine from patients with disorders of propionate metabolism: a beneficial effect of Icarnitine supplementation. Cell Mol Neurobiol. 2012;32:77-82.

22. Fragaki K, Cano A, Benoist JF, Rigal O, Chaussenot A, Rouzier C, Bannwarth S, Caruba C, Chabrol B, Paquis-Flucklinger V. Fatal heart failure associated with CoQ10 and multiple OXPHOS deficiency in a child with propionic acidemia. Mitochondrion. 2011;11:533-6.

23. Baruteau J, Hargreaves I, Krywawych S, Chalasani A, Land JM, Davison JE, Kwok MK, Christov G, Karimova A, Ashworth M, Andersin G, Prunty H, Rahman S, Grünewald S. Successful reversal of propionic acidaemia associated cardiomyopathy: evidence for low myocardial coenzyme Q10 status and secondary mitochondrial dysfunction as an underlying pathophysiological mechanism. Mitochondrion. 2014;17:150-6.

24. Salmi H, Leonard JV and Lapatto R. Patients with organic acidaemias have an altered thiol status. Acta Paediatr. 2012;101:e505-8.

25. Cederbaum Al. Hepatoprotective effects of $S$-adenosyl-L-methionine against alcohol- and cytochrome P450 2E1-induced liver injury. World J Gastroenterol. 2010;16:1366-76.

26. Myles JG, Manoli I, Venditti CP. Effects of medical food leucine content in the management of methylmalonic and propionic acidemias. Curr Opin Clin Nutr Metab Care. 2018;21:42-8.

27. Zhen H, Nakamura K, Kitaura Y, Kadota Y, Ishikawa T, Kondo Y, Xu M, Shimomura Y. Regulation of the plasma amino acid profile by leucine via the system $L$ amino acid transporter. Biosci Biotechnol Biochem. 2015;79:2057-62.

28. Wessels AG, Kluge H, Hirche F, Kiowski A, Shutkowski A, Corrent E, Bartelt J, König B, Stangl GI. High Leucine Diets Stimulate Cerebral Branched-Chain Amino Acid Degradation and Modify Serotonin and Ketone Body Concentrations in a Pig Model. PLoS One. 2016;11:e0150376.

29. Imamura W, Yoshimura R, Takai M, Yamamura J, Kanamoto R, Kato H Adverse effects of excessive leucine intake depend on dietary protein intake: a transcriptomic analysis to identify useful biomarkers. J Nutr Sci Vitaminol (Tokyo). 2013;59:45-55.

30. Gatnau R, Zimmerman DR, Nissen SL, Wannemuehler M, Ewan RC. Effects of excess dietary leucine and leucine catabolites on growth and immune responses in weanling pigs. Anim Sci. 1995;73:159- 
65.

Figures

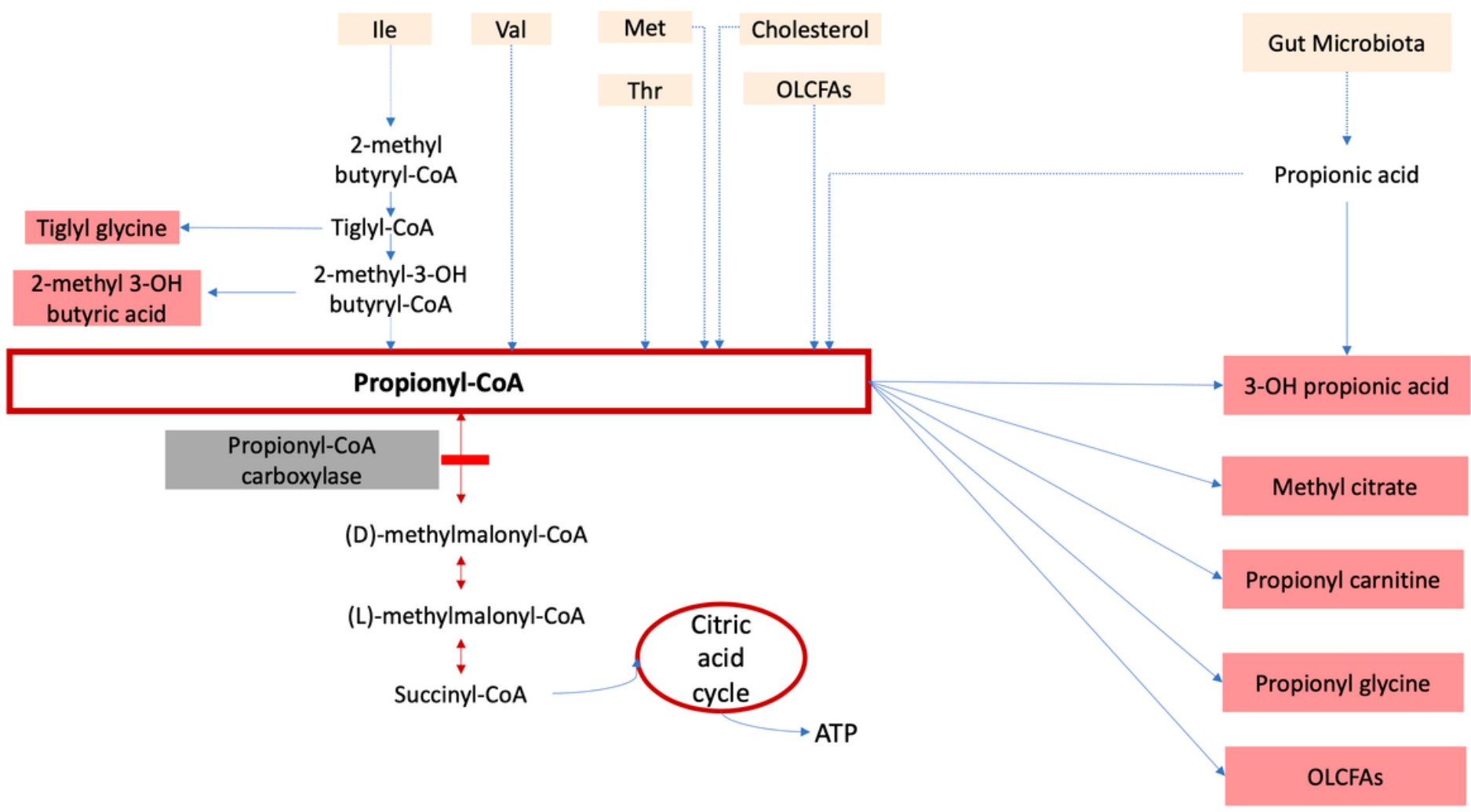

Figure 1

Metabolic pathways in Propionic acidemia. OLCFAs: odd-numbered long-chain fatty acids
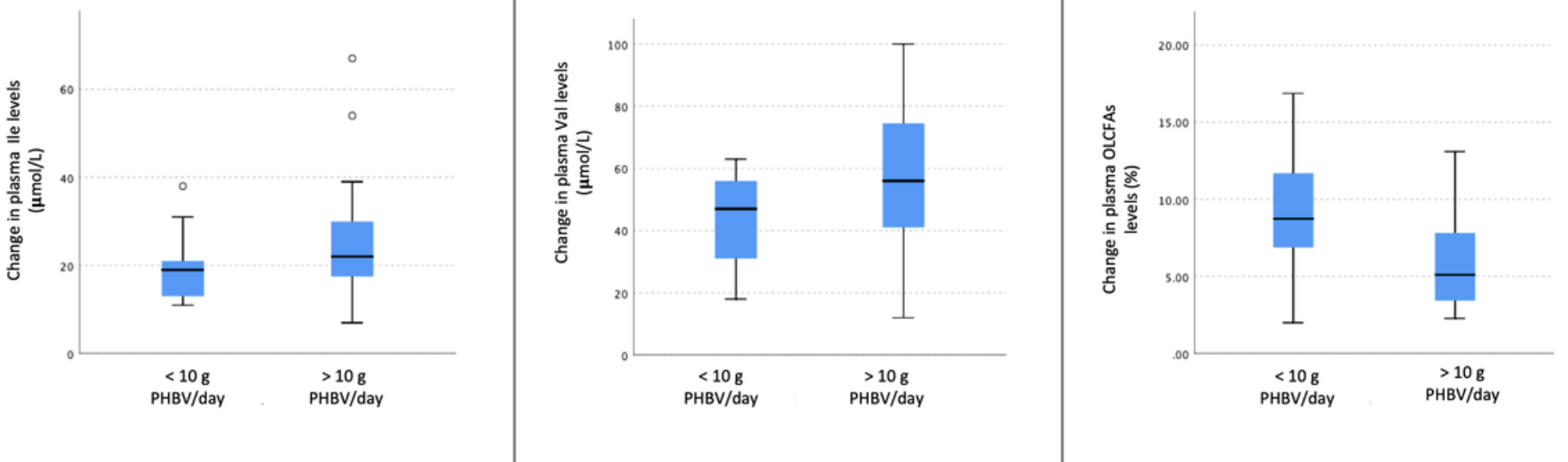

Figure 2 
Plasma Val, lle and OLCFAs with respect to intake of proteins of high biological value (PHBV)
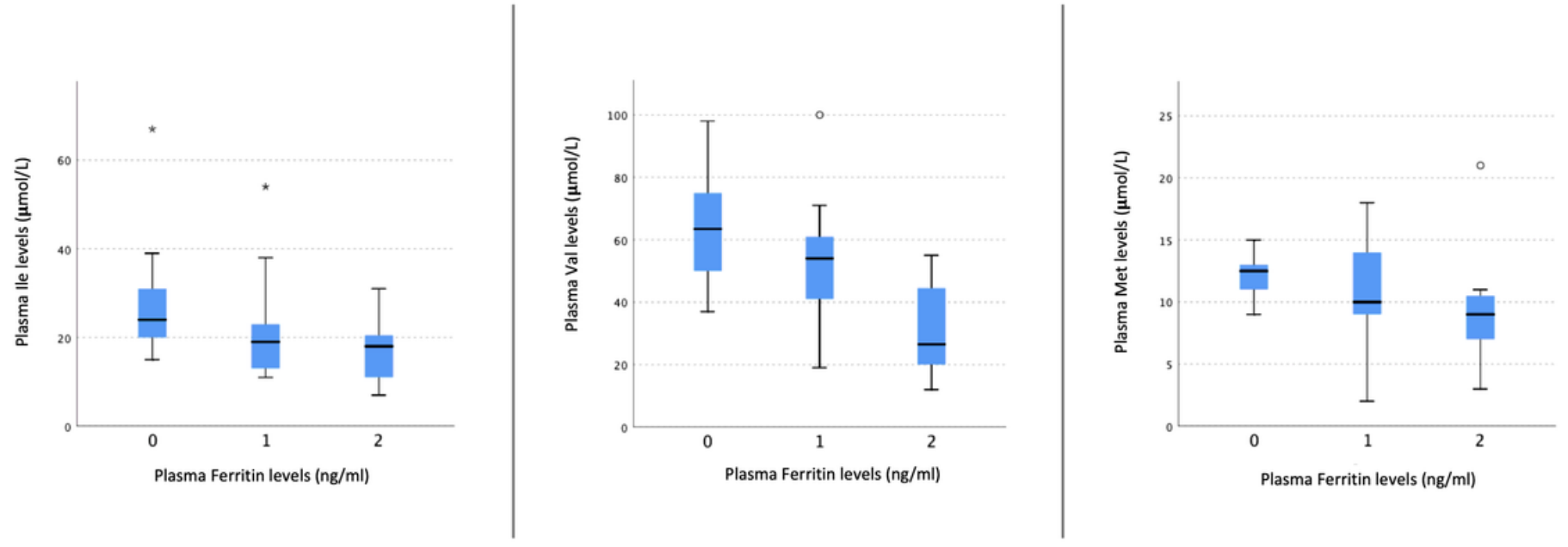

Figure 3

Plasma lle, Val and Met with respect to plasma ferritin. X axis: 0: ferritin $<300 \mathrm{ng} / \mathrm{ml}, 1$ : ferritin $300-1000$ $\mathrm{ng} / \mathrm{ml}$, 2: ferritin: $>1000 \mathrm{ng} / \mathrm{ml}$. 